\title{
Sovereign Debt Crisis: Why in Europe and not Elsewhere?
}

Why have markets been worried about fiscal sustainability in the euro area and not in other advanced economies? Answering this question is critical to understanding the policies needed to exit the current crisis (market conditions may have improved, but significant risks persist) and to avoiding future ones. The fiscal accounts of the United States, United Kingdom and Japan are as weak as those of some of the countries in the euro area that have come under market pressure. If we rank countries by their 2011 deficit-to-GDP ratios, we find Japan first (together with Ireland), the USA fourth and the UK fifth, ahead of Spain (sixth), Portugal (eighth) and Italy (a distant sixteenth). As for the debt-to-GDP ratios, Japan is first and the USA is sixth, just ahead of Portugal and Ireland (the US debt ratio is 102\% while Portugal's is 107\%). Why are markets forgiving the fiscal sins of other advanced economies and not those of the euro area?

One can come up with several reasons: for example, potential growth is perceived to be higher in the USA, and growth is critical for fiscal sustainability. But this explanation does not hold for Japan. Moreover, many claim that high debt levels will be a drag on US growth. There is, however, a common denominator to the experiences of the USA, UK and Japan that may shed light on the benevolent market attitude towards these three economies. This common denominator is the massive intervention by their central banks in the government paper market.

The Bank of England currently holds some $20 \%$ of the securities issued by the UK Treasury, reflecting massive purchases of government paper, especially in 2009. The Fed also holds about $20 \%$ of US Treasury securities (and another $34 \%$ are held by foreign central banks). The share of public debt held by the Bank of Japan is smaller, but the Japanese central bank finances Japanese commercial banks and the latter invest heavily in government paper. Econometric estimates confirm that the presence of central banks in the government paper market has contributed significantly to lowering interest rates on government paper in 2011. Of course, the view that printing money to finance governments is the way to get out of the crisis may sound heretical and must be qualified in two important respects.

It is first necessary to explain why an orthodox approach - frontloaded fiscal tightening to restore credibility - is unlikely to work in isolation in the current circumstances. The reason is that markets now seem to be focusing on short-term rather than long-term developments, possibly due to the high uncertainty that has prevailed over the last few years. In the short run, fiscal tightening causes an output deceleration (and for countries with high debt, it could even cause a temporary increase in the debt-to-GDP ratio). If markets focus on these short-term developments, as econometric evidence suggests was indeed the case in 2011, interest rates may increase when fiscal policy is tightened, which is bad not only for the fiscal accounts but also for the economy. Hence the need for central banks (or other sources of financing for the public sector - see below) to supply liquidity to moderate interest rates during the fiscal adjustment period.

The second point to underscore is that central bank intervention is a complement, not a substitute, to fiscal adjustment. Without fiscal adjustment, central bank intervention would cause higher inflation sooner or later. However, given the current high demand for liquidity, central bank intervention is unlikely to cause immediate inflationary pressures. Rather, it allows for a more gradual fiscal adjustment in countries that are not faced with market pressure. In countries under pressure, where frontloaded fiscal adjustment is necessary, it allows interest rates to decline as fiscal policy is tightened, thus supporting economic activity.

The importance of central bank intervention has recently been confirmed by the success of the longer-term refinancing operation launched by the ECB in December, which facilitated the decline 
in interest rates following the enactment of major fiscal adjustment and structural reform measures in the countries under pressure. That said, the IMF has recommended that the ECB should not have to shoulder the entire burden alone. Even if fully effective, the ECB action would increase the symbiosis between government and bank balance sheets, thus making it more complicated to manage possible future crises. Thus, strengthening the firewalls - the resources made available by euro area governments to support countries that are adjusting - remains necessary.

But managing the current crisis is not all that matters. A much stronger degree of fiscal integration will be needed to avoid the resurgence of euro area fiscal crises in the future. One key difficulty in forging a model of stronger fiscal federalism in the euro area is that the only examples of fiscal federalism all exist within political unions. In Europe a stronger fiscal union must be achieved in the absence of a plan for political union. It is, once again, uncharted territory. The features of euro area fiscal federalism will have to take into account the absence, at least initially, of a political union. At least seven dimensions are relevant in defining a fiscal federalism model.

First, there is a need for constraints - rules and sanctions - to prevent imbalances at the state level from causing problems for other parts of the federation. The recent Fiscal Compact and the decisions that preceded it aim at this by formalising constraints that are similar to those existing in federations, at least in terms of rules, if not of sanctions. It remains to be seen how it will be implemented in practice. Second, there is a need for budget procedures that are sufficiently similar, in terms of both accounting practices and definitions. The Directive included in the so-called six-pack agreement goes in this direction, but it is fairly general and may not be sufficient. Third, there is the issue of how to respond to a fiscal crisis at the state level, should one emerge. In political unions, no special mechanism is needed: if a state within a union has financial problems, the usual bankruptcy procedures apply. But in a political union, the smaller size of local budgets with respect to the federal budget and the perception of indissolubility of the monetary union reduce the risk of contagion to almost zero. In the euro area, the risk of contagion is much higher; hence the need for a mechanism to manage crises. The European Stability Mechanism is meant to play this role. Its effectiveness will have to be assessed over the medium term.

A fourth dimension refers to the role of the centre in absorbing shocks affecting only part of the federation. The stronger the constraints imposed upon fiscal policy at the local level, the smaller will be the possibility of using fiscal policy to respond to idiosyncratic shocks and the more important will be the transfers from the centre to absorb them. The degree of risk sharing is a key characteristic of fiscal federations. In the euro area, risk sharing is being debated, but there is no agreement in this area. Fifth, in federal states the centre has a large budget - fuelled by taxes collected by or transferred to the centre, or by borrowed resources - that can play an important role in responding to common economic shocks in a flexible way. Such a budget does not exist in Europe. Sixth, federal states issue federal securities. There is no agreement to issue eurobonds, in spite of the obvious benefits of supplying a reserve currency alternative to the dollar. Note, however, that the discussion of eurobonds in Europe primarily revolves around their use as a tool for centralising borrowing by individual states. Normally in federations, federal bonds are issued to finance federal spending, not to centralise borrowing to finance decentralised spending. Seventh, federal states have a degree of coordination with regard to tax and expenditure polices that is stronger than the one currently existing in Europe. Stronger coordination would be useful to strengthen economic integration. For example, similar pension treatments would increase labour mobility.

In conclusion, reducing euro area vulnerabilities will require not only monetary and fiscal policies aimed at managing the current crisis but also further progress in strengthening the fiscal union to avoid the resurgence of similar crises in the future. The calm financial market reactions to the EFSF downgrade should not mask this need.

Carlo Cottarelli, Fiscal Affairs Department, International Monetary Fund, Washington, USA 